Creative commons User License: CC BY-NC-ND

Abstracted by: EBSCOhost, Electronic Journals Service (EJS), Google Scholar, Directory of Open Access Journals (DOAJ), Journal Seek, Scientific Commons,

Food and Agricultural Organization (FAO), CABI and Scopus
Journal of Agricultural Extension

Vol. 21 (2) June, 2017

ISSN(e): 24086851; ISSN(Print); 1119944X

http://journal.aesonnigeria.org

http://www.ajol.info/index.php/jae

Email: editorinchief@aesonnigeria.org

\title{
Farmers' Perceptions of Rice Postharvest Losses in Eastern Uganda
}

https://dx.doi.org/10.4314/jae.v21i2.3

\section{Ssebaggala G.L}

Department of Extension and Innovation Studies, College of Agricultural and Environmental Sciences, Makerere University, P.O. Box 7062, Kampala, Uganda.

Email: seba.godfrey@yahoo.com Tel.+256772501068;

\section{Kibwika P}

Department of Extension and Innovation Studies, College of Agricultural and Environmental Sciences, Makerere University, P.O. Box 7062, Kampala, Uganda.

Email: pkibwika@caes.mak.ac.ug or pkibwika@gmail.com ;Tel. +256712566952

\section{Kyazze F.B}

Department of Extension and Innovation Studies, College of Agricultural and Environmental Sciences, Makerere University, P.O. Box 7062, Kampala, Uganda.

Email: fbirungikyazze@caes.mak.ac.ug ;Tel. +256782354233

\section{Karubanga G}

Department of Extension and Innovation Studies, College of Agricultural and Environmental Sciences, Makerere University, P.O. Box 7062, Kampala, Uganda.

Email: amootigabs@gmail.com or gkarubanga@caes.mak.ac.ug; Tel.+256782929971

\section{Abstract}

The cross-sectional survey involving 83 farmers in focus group discussions and 150 individual interviews examined smallholder farmers' perceptions about postharvest losses (PHLs) in in rice in Eastern Uganda. Principal component analysis and logistic regression were used to establish the determinants of farmers' perceived ability to reduce PHLs. Farmers perceive $66 \%$ of the losses occurred in the field-based activities of harvesting, heaping and threshing through spillage, while 34\% occurred in the home-based activities of drying and storage. Quality deterioration was perceived to be highest at harvesting and drying stages. Farmers' perceived themselves least able to to reduce PHLs at the stages where the losses were highest. These perceptions are significantly influenced farm size, awareness of the modes through which losses occur, proportions of rice sold and household characteristics. Interventions to reduce PHLs should intensify awareness and mindset change, commercialization of rice production, best-fit practices and technologies foe smallholder farmers and collective action for groups of farmers to undertake some operations together.

Keywords: Smallholder farmer in Uganda, rice postharvest losses.

\section{Introduction}

Provision of food for the ever increasing world population is still a challenge (World Bank, 2011). In Sub-Saharan African (SSA), where countries are most at risk of food insecurity, efforts have been directed towards increasing agricultural production and productivity (Affognon et al., 2015; Nijbroek \& Andleman, 2016). Nonetheless, 
Creative commons User License: CC BY-NC-ND

Abstracted by: EBSCOhost, Electronic Journals Service (EJS), Google Scholar, Directory of Open Access Journals (DOAJ), Journal Seek, Scientific Commons,

Food and Agricultural Organization (FAO), CABI and Scopus
Journal of Agricultural Extension

Vol. 21 (2) June, 2017

ISSN(e): 24086851; ISSN(Print); $1119944 X$

http://journal.aesonnigeria.org

http://www.ajol.info/index.php/jae

Email: editorinchief@aesonnigeria.org

limited attention has been directed to the reduction of postharvest losses (PHL) especially in cereals (Hodges et al.,

2011; Affognon et al., 2015). For example, the Food and Agriculture Organization (FAO, 2011) reports that in SSA, $13.5 \%$ of the total cereal production including rice is lost during postharvest handling and distribution. Yet rice feeds about half of the world's population (EUCORD, 2012). Accordingly, investing in $\mathrm{PHL}$ reduction is regarded as a quick impact intervention for enhancing food security (Affognon et al., 2015).

In Uganda, rice is among the priority cereal crops for household food and income security (National Development Plans II). Introduction of high yielding varieties (HYVs) such as New Rice for Africa (NERICA) has increased Uganda's production from 132,000 Metric tons in 2003 to 233,000 Metric tons of paddy rice by 2011 (FAO, 2014). However, high PHL in terms of quantity and quality remain a key challenge (Candia \& Masette, 2012; MAAIF, 2012; Nakazi \& Sserunkuuma, 2013). The farmer is the most affected with PHL through loss of quantity of rice available for food and income, and low prices for poor quality rice. Efforts to reduce PHL will only take root if the farmers perceive PHL as a problem that affects them and needs their attention.

Postharvest losses are an integrative phenomenon that results from farmers interacting with technologies/practices and the context in which they operate (World Bank, 2011; Kagbu et al., 2016) and perceptions are central to this phenomenon. In the context of this study, farmers' perceptions are defined as intrinsic factors such as attitudes, values and beliefs about PHLs that inform the willingness and ability to reduce the losses (Martin et al., 2014). This paper determines the farmers' perceptions about the magnitude and nature of PHLs as well as their ability to mitigate these losses. The study was informed by two research questions; viz; (i) how do farmers perceive the extent of PHL in terms of quantity and quality? and; (ii) what determines farmers' perceived ability to reduce such losses?

\section{Theoretical framework}

The study was anchored in the Theory of Planned Behaviour (TPB) (Ajzen, 1991). The theory explains the drivers of human behaviors and actions as shaped by their perceptions. The theory argues that human behavior/actions are usually intentional and are determined by three elements; attitude towards the behavior, subjective norms and behavioral control beliefs. Attitude towards the behavior refers to the person's beliefs and values about the outcome of the behavior while the subjective norms are about the beliefs about what other people that the person considers important think s/he should do. The behavioral control beliefs concern the person's beliefs about his/her; ability to perform the behavior, access and control over resources needed to perform the behavior. Such control beliefs helped to guide the study to identify the farm and farmer characteristics to be assessed as predictors of farmers' perceived ability to reduce PHL. 
Creative commons User License: CC BY-NC-ND

Abstracted by: EBSCOhost, Electronic Journals Service (EJS),

Google Scholar, Directory of Open Access Journals (DOAJ),

Journal Seek, Scientific Commons,

Food and Agricultural Organization (FAO), CABI and Scopus
Journal of Agricultural Extension

Vol. 21 (2) June, 2017

ISSN(e): 24086851; ISSN(Print); 1119944X

http://journal.aesonnigeria.org

http://www.ajol.info/index.php/jae

Email: editorinchief@aesonnigeria.org

The PHL especially on the farm result from farmer practices or behaviours, which are in conformity with their norms and belief in their capabilities to among other things reduce the losses. It therefore can be argued that what farmers do that leads to PHLs is intentional but farmers have good reasons for continuing to do that. This is based on what they perceive to be the extent of the losses and influenced by the opinions of the people they consider important in the community. Belief in their own potential to change behavior (practices) to reduce PHL will influence their search for and uptake of appropriate technologies.

Based on TPB, farmers who believe that the PHL significantly affects their livelihood in terms of food availability and income will have strong intention to take up new knowledge and technologies to reduce the losses (Rogers, 1995; Seline et al., 2015). Conversely, those who think PHL do not have significant impact on their livelihood are unlikely to want to change the status quo. The conviction that one can successfully undertake measures to reduce $\mathrm{PHL}$ is indicative of the readiness to change behavior and reduce PHLs. Consequently, ones' perceived ability (selfefficacy) will influence the use of practices and technologies to reduce PHLs. Selfefficacy refers to the conviction that given access and control to resources, one can successfully execute the behaviour required to produce an outcome; in this case PHL reduction (Ajen, 1991).

\section{Methodology}

The study was conducted in Iganga and Namutumba districts in Eastern Uganda, which according to MAAIF (2011) are the leading producers of rice in the region. In addition, Eastern region accounts for $63 \%$ of the total weight grain loss of rice in Uganda (African Postharvest Loss Information System [APHLIS], 2012). Together, Iganga and Namutumba districts produce $30 \%$ of all the rice produced in Eastern Uganda. In the two districts, farmers grow a variety of food and cash crops. However, rice is a priority crop (Odogola, 2006; Tokida et al., 2014). A descriptive cross-sectional survey was conducted among rice farmers in the study districts to obtain their opinions on the perceived magnitude of the PHLs and the perceived ability to undertake measures to reduce the losses. Data from the survey was complemented by Focus Group Discussions (FGDs) aimed at obtaining collective opinions on the extent of PHLs and their control measures.

Four major rice-producing sub-counties within the study districts were purposively selected (Buyanga and Namalemba from Iganga district, Nsinze and Kibale from Namutumba district) for the study. With guidance from sub-county extension workers and local council chairpersons, four major rice producing villages were selected from each sub-county as the study sites. For each village, a list of rice growing farmers were generated by the village leaders as the sampling frame. The list comprised of 802 farmers that grew rice in the first season of 2015 in the four villages. Using villages as strata, a $5 \%$ proportionate stratified sampling strategy was employed to determine the number of farmers selected from each of the villages. Within each village, a simple random sampling strategy was employed and a sample of 150 
Creative commons User License: CC BY-NC-ND

Abstracted by: EBSCOhost, Electronic Journals Service (EJS), Google Scholar, Directory of Open Access Journals (DOAJ), Journal Seek, Scientific Commons,

Food and Agricultural Organization (FAO), CABI and Scopus
Journal of Agricultural Extension

Vol. 21 (2) June, 2017

ISSN(e): 24086851; ISSN(Print); $1119944 X$

http://journal.aesonnigeria.org

http://www.ajol.info/index.php/jae

Email: editorinchief@aesonnigeria.org

farmers were selected to participate in the individual face-to-face semi-structured interviews.

First, nine focus group discussions were conducted to explore farmer perceptions towards the magnitude and how post-harvest losses occur and their reduction strategies. Eighty-three farmers (43 males and 40 females) were purposively selected to participate in the focus group discussion based on their knowledge and experience in rice production. The focus groups generated the items for the survey instrument. Semi-structured interviews were used to gather data including sociodemographic characteristics of the households; experience in rice production; access to markets and extension services; availability of labour for farm operations (labour was considered part-time if hired, otherwise it was full-time); extent of quality deterioration and grain damage at different stages; and ability to reduce the losses.

Farmers scored estimated grain loss through the different stages of post-harvest as follows; $0=$ Not at all, $1=$ Negligible/very low losses, 2= low losses, $3=$ High losses, $4=$ Very high losses. Quality deterioration through the post-harvest process was scored on a scale of $1-5$ as follows; $1=$ No quality loss, $2=$ Very low quality loss, $3=$ Low quality loss, $4=$ High quality loss, and; $5=$ Very high quality loss. For each stage, an aggregate index for the perception on quality deterioration was estimated by the average score. A dichotomous score was used for farmers' perceived ability to reduce the losses at three critical stages of the post-harvest process namely, harvesting, threshing and drying. Here, a score of 1 indicated that farmer believed that they had the ability to reduce PHL and a score of zero meant that farmer believed they did not have the ability to reduce the PHL.

A panel of experts comprising of four scholars from Makerere University judged the content validity of the survey instrument appropriate for the research objectives. Prior to its use, the instrument was pre-tested for on 15 farmers from a sub-county (not included in survey) for reliability. A Spearman Brown coefficient of 0.8 for a testretest reliability, affirming that the instrument was reliable.

The qualitative data from FGDs were subject to content analysis to synthesize the emergent issues. The qualitative information was used to provide additional explanations and anecdotal evidence to complement the quantitative data. Data from the survey were analyzed using Statistical Product for Service Solution (SPSS) version 16. Means were also used to generate the weighted average scores of the contributions of the different modes of physical grain loss and quality deterioration after harvest. Furthermore, a principal component analysis was run to identify the factors likely to influence farmer's perceived ability to reduce post-harvest losses. The principal component analysis was preferred as a data reduction technique to aggregate related variables together as principal component factors. The principal component factors were then treated as predictor variables and subjected to a logistic model analysis to determine the likelihood that a farmer will perceive himself/herself to have the capability to curb PHLs at the stages of harvesting, threshing and drying where the losses are considered highest. The model specification is as follows: 
Creative commons User License: CC BY-NC-ND

Abstracted by: EBSCOhost, Electronic Journals Service (EJS),

Google Scholar, Directory of Open Access Journals (DOAJ),

Journal Seek, Scientific Commons,

Food and Agricultural Organization (FAO), CABI and Scopus

\section{Journal of Agricultural Extension}

Vol. 21 (2) June, 2017

ISSN(e): 24086851; ISSN(Print); 1119944X

http://journal.aesonnigeria.org

http://www.ajol.info/index.php/jae

Email: editorinchief@aesonnigeria.org

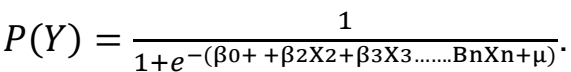

Equation 1

$\mathrm{P}(\mathrm{Y})$ is the probability of a farmer's perceived ability to reduce rice PHLs at harvesting, threshing and drying

$X_{1}$ to $X_{n}$ are principal component factors (predictor variables) presumed to predict the probability of the farmer's perceived ability to reduce rice PHLs at harvesting, threshing and drying

$\beta_{0}$ is the $Y$-intercept

$\beta_{1}$ to $\beta_{6}$ are the coefficients (weights) attached to each of the predictors $x_{1}$ to $x_{6}$, where

$\mathrm{X}_{1}=$ Modes of quality deterioration

$\mathrm{X}_{2}=$ Modes of physical grain loss

$\mathrm{X}_{3}=$ Utilization of rice in the household

$\mathrm{X}_{4}=$ Labour availability on the farm

$\mathrm{X}_{5}=$ Household characteristics

$\mathrm{X}_{6}=$ Land for rice production

$\mu$ is the error term. The equation can also be simplified as illustrated below:

$\ln \left[\frac{P(Y)}{1-P(Y)}\right]=Z=\beta_{0}+\beta_{1} X_{1}+\beta_{2} X_{2}+\beta_{3} X_{3}+\ldots . B_{n} X_{n}+\mu \ldots \ldots \ldots \ldots \ldots \ldots \ldots \ldots$ Equation 2

\section{Results and Discussion}

\section{Description of Respondents}

Table 1 presents the socio-demographic characteristics of the respondents whose average age was 42 years. The majority $(61 \%)$ of the respondents were males and $39 \%$ were females. About $90 \%$ were from male headed households with implications on decision making. About $56 \%$ of the respondents could access credit to cater for costs related to postharvest.

\section{Table 1: Socio-demographic characteristics of respondents}

\begin{tabular}{|c|c|c|c|}
\hline io-demographic characteristics & $\begin{array}{l}\text { Percentage } \\
(n=150)\end{array}$ & Mean & $\begin{array}{l}\text { Standard } \\
\text { Deviation }\end{array}$ \\
\hline
\end{tabular}

Gender of male farmers??

Male headed households

90.00

Access to credit for rice production

56.00

Off farm income

36.00

Age (years)

No of years spent in education

Total land cultivated (acres)

Total land allocated to rice (acres)

Household size

Full time $\mathrm{HH}$ members

Part time $\mathrm{HH}$ members

Paddy rice production per acre (Kgs)

Proportion of rice sold (\%)

Distance to Mill $(\mathrm{Km})$

Number of channels used to receive extension advice

Experience in rice production (years)

Source: Household survey 2015

$\begin{array}{cc}41.87 & 12.39 \\ 6.08 & 3.3 \\ 4.20 & 2.80 \\ 1.40 & 0.73 \\ 8.83 & 3.32 \\ 2.70 & 1.82 \\ 3.63 & 2.86 \\ 943.0 & 535.0 \\ 70.5 & 19.9 \\ 1.87 & 1.64 \\ 3.48 & 1.54 \\ & \\ 16.7 & 10\end{array}$


Creative commons User License: CC BY-NC-ND

Abstracted by: EBSCOhost, Electronic Journals Service (EJS),

Google Scholar, Directory of Open Access Journals (DOAJ),

Journal Seek, Scientific Commons,

Food and Agricultural Organization (FAO), CABI and Scopus
Journal of Agricultural Extension

Vol. 21 (2) June, 2017

ISSN(e): 24086851; ISSN(Print); 1119944X

http://journal.aesonnigeria.org

http://www.ajol.info/index.php/jae

Email: editorinchief@aesonnigeria.org

The majority (89\%) of the respondents attained some formal education and $11 \%$ had no formal education. On average, a household cultivated 4.2 acres and of this, 1.4 acres (35\%) were for rice. The mean household size was nine which nearly doubles the national average of 4.7 (See UBOS, 2014). Large household size also implies higher demand for food and other needs. On average, farmers produced about 943 kilograms of rice per acre. This yield is close to the national average of 1000 kilograms per acre (Elepu \& Dalipagic, 2014). The distance to the nearest mill was almost half of the $3.5 \mathrm{~km}$ reported by Nakazi and Sserunkuuma (2013) though in different districts in the same region. The farmers on average had accessed agricultural knowledge from three channels mainly radio, extension workers and demonstrations

\section{Perceived Magnitude of Post-Harvest Losses}

Farmers estimated what they perceived to be the postharvest losses at the various stages both in the field and at home. The field-based stages include; harvesting, heaping and threshing, while the home-based stages were drying, winnowing and storage. Table 2represents the perceived losses at the different stages.

Table 2: Perceived proportion of losses in rice at different stages of post harvest

\begin{tabular}{lc}
\hline Stages & $\begin{array}{c}\text { Perceived proportion of } \\
\text { losses }(\%)\end{array}$ \\
\hline Harvesting & 30.99 \\
Heaping & 10.86 \\
Threshing & 24.53 \\
Drying & 13.13 \\
Winnowing & 12.18 \\
Storage & 8.3 \\
\hline
\end{tabular}

In the farmers' view, most of the postharvest losses in terms of grain loss occur in the field-based activities as compared to the home-based activities. The harvesting stage contributes the highest losses (31\%) followed by threshing (25\%) while heaping is about $11 \%$ of the estimated total losses. A similar pattern was observed by Appiah et al. (2011) in Ghana. This was so because of spillage associated with the post-harvest practices.

The home-based stages accounted for only $33 \%$ of the total grain losses taking place mainly at drying and winnowing. Storage contributed least to grain losses $(8.3 \%)$ contrary to Rugumamu (2009) who found that in Tanzania, farmers perceived highest losses to occur during storage of maize. In the home-based processes for example, farmers ensured that the drying yards were clean or dried the rice on tarpaulins. In addition, the farmers attached more value to the rice that gets home and would do everything possible to avoid further grain losses. Unlike for maize, there are less storage pests for rice. Because of its commercial value, farmers 
Creative commons User License: CC BY-NC-ND

Abstracted by: EBSCOhost, Electronic Journals Service (EJS),

Google Scholar, Directory of Open Access Journals (DOAJ),

Journal Seek, Scientific Commons,

Food and Agricultural Organization (FAO), CABI and Scopus
Journal of Agricultural Extension

Vol. 21 (2) June, 2017

ISSN(e): 24086851; ISSN(Print); 1119944X

http://journal.aesonnigeria.org

http://www.ajol.info/index.php/jae

Email: editorinchief@aesonnigeria.org

ensured that the rice is stored in bags, also for easy estimation of the quantity stored. Most often they did not store rice for long as it was quickly sold off to earn income to meet household needs.

\section{Mechanisms for Grain Loss}

Table 3 shows the average scores of mechanisms though which grain is lost at different stages of postharvest process.

Table 3: Average scores of perceived modes of grain loss at different stages the postharvest process

\begin{tabular}{lcccccccc}
\hline Stages & $\begin{array}{c}\text { Shattering } \\
\text { \& Spillage }\end{array}$ & $\begin{array}{c}\text { Incomplete } \\
\text { harvesting }\end{array}$ & $\begin{array}{l}\text { Mixing } \\
\text { of grain } \\
\text { \& chaff }\end{array}$ & $\begin{array}{l}\text { Birds \& } \\
\text { rodents }\end{array}$ & Theft & Rotting & $\begin{array}{l}\text { Pest } \\
\text { infestation }\end{array}$ & $\begin{array}{l}\text { Moisture } \\
\text { migration }\end{array}$ \\
\hline Harvesting & 2.79 & 1.87 & 0 & 0 & 0 & 0 & 0 & 0 \\
Heaping & 2.49 & 0 & 0 & 0 & 0.95 & 0 & 0 & 0 \\
Threshing & 3.34 & 0 & 3.18 & 0 & 0.97 & 0 & 0 & 0 \\
Drying & 2.77 & 0 & 0 & 2.66 & 0.81 & 1.15 & 0 & 0 \\
Winnowing & 2.63 & 0 & 2.71 & 0 & 0.79 & 0 & 0 & 0 \\
Storage & 1.73. & 0 & 0 & 2.48 & 0 & 0.65 & 0.89 & 0.81 \\
\hline
\end{tabular}

Throughout all the postharvest stages, shattering and spillage contribute the highest grain losses. Separation of grain from chaff especially at threshing and winnowing is another mode through which substantial losses of grain incurred. Birds and rodents caused losses at drying and storage. These losses were attributed to the technologies and practices used at the different stages. For example, at harvesting, the losses are attributed to the use of sickle, which is rudimentary, and inefficient. Appiah et al. (2011) also estimated higher losses associated with using a sickle compared to panicle reaping with a knife.

Interventions for reduction of postharvest losses need to target the stages where the highest PHLs occur. Based on this study, efforts need to be directed at improving technologies and practices that reduce shattering, spillage and inefficient separation of grain from chaff, as these were the major modes through which grain was lost. Lost grain is lost food and income to the farmers after they have invested substantially to produce the grain.

Use of tarpaulins, for example, can reduce spillage at threshing and drying. In the FGDs, high spillage losses during drying were attributed to non-use of improper use of tarpaulins and damage by domestic birds/animals. Similar findings regarding the PHLs due to free ranging and other wild birds were noted by Rugumamu (2009) to case significant losses in maize.

Farmers' Perception of Qquality deterioration During Post-harvest Processing Figure 1 presents farmers' perceptions on quality deterioration at the various stages of the postharvest process. 
Creative commons User License: CC BY-NC-ND

Abstracted by: EBSCOhost, Electronic Journals Service (EJS),

Google Scholar, Directory of Open Access Journals (DOAJ), Journal Seek, Scientific Commons,

Food and Agricultural Organization (FAO), CABI and Scopus
Journal of Agricultural Extension

Vol. 21 (2) June, 2017

ISSN(e): 24086851; ISSN(Print); 1119944X

http://journal.aesonnigeria.org

http://www.ajol.info/index.php/jae

Email: editorinchief@aesonnigeria.org

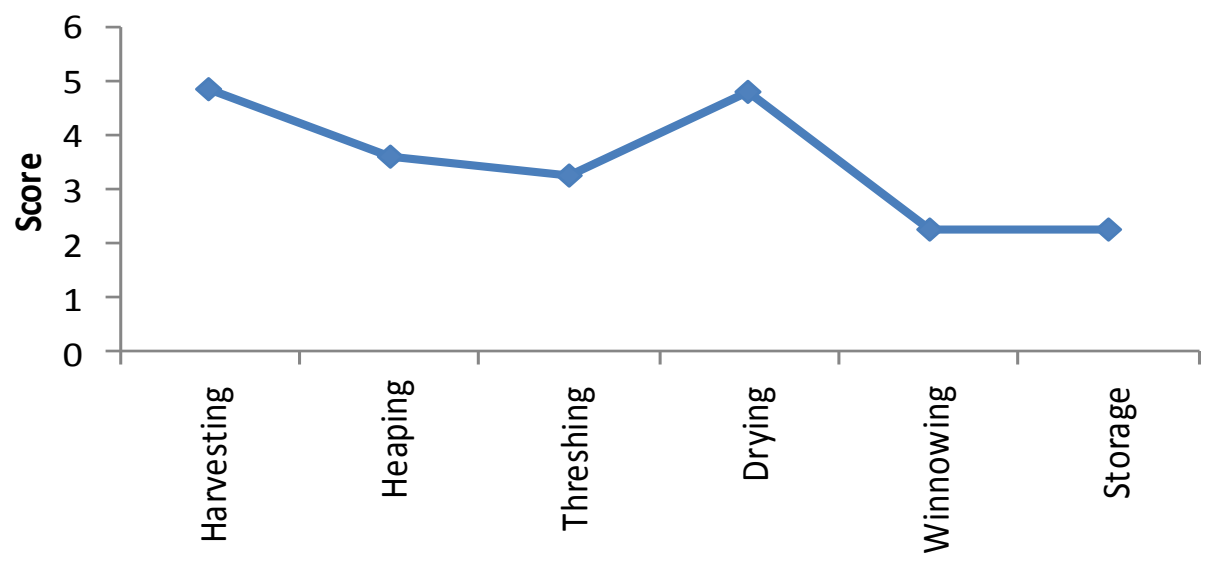

PHH processes

Perceived contribution to quality deterioration

Figure 1: Perceived quality deterioration through stages in the post-harvest process

Figure 1 shows that farmers recognized quality deterioration of rice at all stages of postharvest processes. In the farmers' opinion, harvesting and drying were the stages highest level of quality deterioration occured. At harvesting, this is attributed to early and late harvesting of rice. The non-uniform maturity of the varieties and sometimes labour shortage are some of the reasons for early or late harvesting. The non-selective nature of harvesting by bundling and cutting leads to contamination of rice with weeds (e.g. striga), which also affected the quality of rice. At drying, quality was lost either due to over-drying leading to development of fissures that caused broken grains or inadequate drying that leads to grain discolouration. The practices that contributed to quality deterioration at drying include; i) drying rice on bare ground; ii) over-drying for more than the recommended three hours per day; iii) failure to turn rice regularly during drying; iv) contamination by droppings of domestic animals and birds and $\mathrm{v}$ ) wetting of rice by rain. While farmers were aware of the effects of these practices on the quality of rice, they continue with the practices due to some constraints. For example, while farmers were aware that drying rice for more than three hours a day may lead to broken grain during milling, they did so because of unpredictability of the weather. Farmers in most developing countries rely on sun drying implying that variability in weather affects the $\mathrm{PHH}$ operations often increasing PHLs (Hodges et al., 2011; Adebayo et al., 2014). Technologies such as using simple solar powered flat-bed dryers which can help to solve the problem are not affordable by farmers.

At heaping, quality degraded through heat build-up from molds resulting into yellowing of rice grain, loss of taste and aroma and at threshing it is through varietal mixing and contamination with mud and other foreign matter. Winnowing and storage are the stages with the lowest levels of quality deterioration. At storage quality 
Creative commons User License: CC BY-NC-ND

Abstracted by: EBSCOhost, Electronic Journals Service (EJS), Google Scholar, Directory of Open Access Journals (DOAJ), Journal Seek, Scientific Commons,

Food and Agricultural Organization (FAO), CABI and Scopus
Journal of Agricultural Extension

Vol. 21 (2) June, 2017

ISSN(e): 24086851; ISSN(Print); 1119944X

http://journal.aesonnigeria.org

http://www.ajol.info/index.php/jae

Email: editorinchief@aesonnigeria.org

deterioration was through improper storage facilities resulting from moisture migration causing yellowing of the grains.

\section{Determinants of Farmers' Perceived Potential to Reduce PHLs}

To fully understand what shapes the farmers' perceptions on their ability to curb PHLs, a principal component analysis was performed. Based on this analysis (Appendix 1) six principal factors were extracted as determinants of farmers' perceptions to curb PHLs. Factor 1-6, extracted the largest amount of variance $(56.98 \%)$ and had Eigen values greater than 1 (Kaiser, 1960). Factor 1 accounted for $18.7 \%$ of the variance, Factor 2 for $9.63 \%$, Factor 3 for $8.8 \%$, Factor 4 for $8.1 \%$, Factor 5 for $6.2 \%$ and Factor 6 for $5.5 \%$.

The six principal component factors were then treated as predictor variables and subjected to a logistic model analysis to determine the likelihood that farmers will perceive themselves capable of curbing PHLs at various stages in the postharvest process, namely; harvesting, threshing and drying where the losses are perceived to be the highest by farmers. The results of the model are presented in the Table 4.

Table 4: Perceived factors to reduce PHLs

\begin{tabular}{|c|c|c|c|c|}
\hline Stage & Determinants & B & Wald & $\operatorname{Exp}(B)$ \\
\hline \multirow[t]{6}{*}{ Harvesting } & Modes of grain quality deterioration & 0.326 & 2.409 & 1.386 \\
\hline & $\begin{array}{l}\text { Contribution of various modes of physical } \\
\text { grain loss }\end{array}$ & -.098 & .220 & .906 \\
\hline & Utilization of rice in the household & -0.291 & 1.780 & .747 \\
\hline & Labour availability on the farm & -0.146 & .479 & .864 \\
\hline & Household characteristics & -.020 & .009 & .980 \\
\hline & Potential for expansion of rice production & .435 & $4.054^{*}$ & 1.545 \\
\hline \multirow{6}{*}{ Threshing } & Modes of grain quality deterioration & .342 & 2.081 & 1.407 \\
\hline & $\begin{array}{l}\text { Contribution of various modes of physical } \\
\text { grain loss }\end{array}$ & -.769 & 7.183* & .464 \\
\hline & Utilization of rice in the household & -.909 & $11.986^{\star}$ & .403 \\
\hline & Labour availability on the farm & 112 & .224 & 1.119 \\
\hline & Household characteristics & .018 & .005 & 1.018 \\
\hline & Potential for expansion of rice production & .709 & $6.338^{*}$ & 2.031 \\
\hline \multirow[t]{6}{*}{ Drying } & Modes of grain quality deterioration & -.309 & 1.852 & .734 \\
\hline & $\begin{array}{l}\text { Contribution of various modes of physical } \\
\text { grain loss }\end{array}$ & -.530 & $4.013^{*}$ & .589 \\
\hline & Utilization of rice in the household & -.588 & $6.310^{*}$ & .556 \\
\hline & Labour availability on the farm & .081 & .128 & 1.084 \\
\hline & Household characteristics & .471 & $3.815^{\star}$ & 1.602 \\
\hline & Potential for expansion of rice production & .068 & .087 & 1.070 \\
\hline
\end{tabular}

Table 4 indicates that not all the six factors had influence on the farmers' perceptions about their perceived capability to reduce PHLs at the various stages. At harvesting, the logistic model identified "potential for expansion of rice production" as the 
Creative commons User License: CC BY-NC-ND

Abstracted by: EBSCOhost, Electronic Journals Service (EJS), Google Scholar, Directory of Open Access Journals (DOAJ), Journal Seek, Scientific Commons,

Food and Agricultural Organization (FAO), CABI and Scopus
Journal of Agricultural Extension

Vol. 21 (2) June, 2017

ISSN(e): 24086851; ISSN(Print); 1119944X

http://journal.aesonnigeria.org

http://www.ajol.info/index.php/jae

Email: editorinchief@aesonnigeria.org

significant factor that is likely to influence farmers' perceptions about their capability to curb PHLs. Potential for expansion of rice production had a positive co-efficient and was significant at $p \leq 0.05$. This implies that, farmers that have the potential to increase acreage under rice are more likely to perceive themselves capable of curbing PHLs at harvesting and threshing. This is probably due to the commercial orientation that is associated with larger acreage and the likelihood that such farmers tend to seek for more efficient technologies in their operations as opposed to reliance on human labor among the smallholder farmers. Tiamiyu et al. (2009) argues that commercialization empowers farmers to get access to resources, which they can plough back into production and postharvest handling activities. Further, they tend to minimize losses of both physical grain and quality in order to maximize on output and income. This in itself is a challenge given that most of the rice farmers are indeed smallholders and expansion may be constrained by availability and/or access to additional land for expansion. A possible way to address this could be consolidation of smallholder farms where farmers can collectively acquire more efficient technologies for harvesting, but this also implies synchronization of the farm operations among the smallholder farmers.

In addition to the potential for expansion of rice production, farmers' awareness about the mode of physical grain loss and how rice is utilized in the household had a significant influence on the farmers' perception on capability to curb PHLs at the threshing stage $(p<0.05)$. The negative coefficient of awareness about modes of physical gain loss implies that despite farmers' awareness of the modes of grain loss, they perceived themselves less able to reduce the losses at threshing as their awareness of the modes through which the losses occur increases possibly due to lack of best-fit practices and technologies. A farmer who is aware of the modes of losses is also likely to know the technologies and practices required to reduce those losses. Affordability of the required technologies and practices is a major factor shaping farmer's perceptions on ability to reduce losses. Discussions with the farmers during FGDs revealed that they were aware that spillage was among the major modes of physical grain loss at threshing and that a thresher would substantially reduce these losses, however they could not afford to purchase/hire a thresher.

Household characteristics (years of experience, age of respondent and total household size) had a positive and statistically significant influence on farmers' perception about capability to curb PHLs $(p<0.1)$. This implies that as the years of experience and household size increase, the more likely a farmer will perceive themselves as having the capability to curb PHLs. Experience reflects accumulation of knowledge and skill, which in turn provides options to the farmer to curb PHLs. Furthermore, household size is a proxy of family labour availability for post-harvest activities. Rice postharvest handling activities are labour intensive, tedious and manually done compared to other crops such as maize; thus making labour a key requirement in reduction of PHLs (Kijima et al., 2008; Issa, 2016). Therefore, a farmer with larger household is more likely to perceive himself as having capability compared to those with a smaller household.

Contribution of various modes of physical grain loss and proportions rice sold or consumed at the household level had a negative but significant coefficients at threshing and drying stages ( $p \leq 0.05)$. This implies that as households increase the 
Creative commons User License: CC BY-NC-ND

Abstracted by: EBSCOhost, Electronic Journals Service (EJS),

Google Scholar, Directory of Open Access Journals (DOAJ),

Journal Seek, Scientific Commons,

Food and Agricultural Organization (FAO), CABI and Scopus
Journal of Agricultural Extension

Vol. 21 (2) June, 2017

ISSN(e): 24086851; ISSN(Print); 1119944X

http://journal.aesonnigeria.org

http://www.ajol.info/index.php/jae

Email: editorinchief@aesonnigeria.org

proportion of rice consumed the less likely they perceive themselves capable of curbing PHLs. This implies subsistence farmers are less likely to take initiatives to curb post-harvest losses in rice compared to commercially orientated farmers. In terms of practical intervention, the subsistence farmers will require more sensitization to influence them to change to practices and technologies that curb PHLs.

\section{Conclusion and Recommendations}

Change in perceptions is the starting point for influencing change of behavior of smallholder farmers towards reducing PHLs in rice. Farmers are aware of the losses that take place at different stages in the postharvest process (i.e. harvesting, heaping, threshing, drying and storage). In their own view, over $66 \%$ of the losses take place in the field-based processes while about 34\% take place in the homebased processes. The modes through which losses occur are also known. Most farmers, however, perceive themselves unable to reduce the PHLs at the stages where the losses occur most. This perception is shaped by lack of knowledge and availability of best-fit practices and technologies for the smallholder farmers. The shift from subsistence to commercial orientation is the major leap towards influencing behaviours that support reduction of post-harvest losses in rice. This can be achieved by both expansions of farms and increased productivity to provide more for sale than domestic consumption. Labour availability in the household is also a critical factor influencing post-harvest losses though the labour saving technologies available are unaffordable by the majority of farmers.

Overall, it is the scale of operation, commercial orientation and labor efficiency that most often influence positive attitudes towards curbing PHLs among smallholder farmers. Unlike the other attributes, most farmers may not have the opportunity to expand their area under rice production due to limitation of access to land. In such cases, coordination of the smallholder farmers to organize themselves and synchronize their operations is a plausible option for them to collectively operate like and still enjoy the benefits of a large commercial oriented farmer. In undertaking interventions for reduction of PHLs, the smallholder and subsistence farmers will require more sensitization.

\section{Declaration of Conflicting Interest}

The author(s) declare no potential conflicts of interest with respect to the research, authorship, and/or publication of this article

\section{Acknowledgement}

Support for this research was made possible through a capacity building competitive grant "Training the next generation of scientists" provided by the Carnegie Cooperation of New York through the Regional Universities Forum for Capacity Building in Agriculture (RUFORUM). 
Creative commons User License: CC BY-NC-ND

Abstracted by: EBSCOhost, Electronic Journals Service (EJS), Google Scholar, Directory of Open Access Journals (DOAJ), Journal Seek, Scientific Commons,

Food and Agricultural Organization (FAO), CABI and Scopus

\section{Journal of Agricultural Extension}

Vol. 21 (2) June, 2017

ISSN(e): 24086851; ISSN(Print); 1119944X

http://journal.aesonnigeria.org

http://www.ajol.info/index.php/jae

Email: editorinchief@aesonnigeria.org

\section{Reference}

Adebayo, B. A., Ndunguru, G., Mamiro, P., Alenkhe, B., Mlingi, N., \& Bekunda, M. (2014). Postharvest food losses in a maize-based farming system of semi-arid savannah area of Tanzania. Journal of stored products research,.57, 49-57.

Affognon, H., Mutungi, C., Sanginga, P., \& Borgemeister, C. (2015). Unpacking postharvest losses in sub-Saharan Africa: A meta-analysis. World Development, 66, 49-68.

Ajzen, I. (1991). The theory of planned behaviour. Organizational Behaviour and Human Decision Processes, 50, 179-211.

Alliance of African Green Revolution [AGRA]. (2014). Africa Agriculture Status report. Climate change and smallholder agriculture in sub-Saharan Africa, Nairobi, Kenya. Issue No. 2. ISSN 2313-5387.

Africa Postharvest Loss Information System [APHLIS]. (2012). A transitional network of cereal grain experts. Estimated postharvest losses- 2003-2015. Available on http://www.aphlis.net.

Appiah, F., Guisse, R., \& Dartey, P. K. A. (2011). Postharvest losses of rice from harvesting to milling in Ghana. Journal of stored products and postharvest research, 2(4), 64-71.

Candia, A., \& Masette. M. (2012). Physical quality and safety assessment of selected varieties of local paddy and milled rice processed by cottage rice mills in Uganda. Uganda Journal of Agricultural Sciences, 13(2),127-138.

Elepu, G., \& Dalipagic, I. (2014). Agriculture value chain analysis in Northern Uganda. Action against Hunger.

European Cooperative for Rural Development [EUCORD]. (2012). Rice Sector Development in East Africa: A desk study prepared for the Common Fund for Commodities March 2012.

Food and Agriculture Organization [FAO]. (2011). Global food losses and food WasteExtent, causes and prevention. Rome.

Food and Agriculture Organization [FAO]. (2014). The State of Food and Agriculture: Innovation in family farming: Food and Agriculture Organization of the united nations Rome.

Hodges, R. J., Buzby, J. C., \& Bennett, B. (2011). Postharvest losses and waste in developed and less developed countries: Opportunities to improve resource use. Journal of Agricultural Science, 149(1), 37-45.

Issa, F. O. (2016). Farmers Perception of the Quality and Accessibility of Agrochemicals in Kaduna and Ondo States of Nigeria: Implications for Policy. Journal of Agricultural Science, 20(1), 81-95.

Kagbu, J. H., Omokore, D. F., \& Akpoko, J. G. (2016). Adoption of Recommended Rice Production Practices among Women Rice Farmers in Nasarawa State, Nigeria. Journal of Agricultural Extension, 20(1), 107-120.

Kaiser, H. F. (1960). The application of electronic computers to factor analysis. Educational and Psychological Measurement, 20, 141-151.

Kiaya, V. (2014). Postharvest losses and strategies to reduce them. Action Contre la Faim (ACF).

Kijima, Y., Otsuka, K., \& Sserunkuuma, D. (2008). Assessing the impact of NERICA on income and poverty in central and western Uganda. Agricultural Economics, 38(3), 327-337.

Martins, A. G., Goldsmith, P., \& Moura, A. (2014). Managerial factors affecting postharvest loss: The case of Mato Grosso Brazil. International Journal of Agricultural Management, 3(4), 200-209. 
Creative commons User License: CC BY-NC-ND

Abstracted by: EBSCOhost, Electronic Journals Service (EJS),

Google Scholar, Directory of Open Access Journals (DOAJ),

Journal Seek, Scientific Commons,

Food and Agricultural Organization (FAO), CABI and Scopus

\section{Journal of Agricultural Extension}

Vol. 21 (2) June, 2017

ISSN(e): 24086851; ISSN(Print); 1119944X

http://journal.aesonnigeria.org

http://www.ajol.info/index.php/jae

Email: editorinchief@aesonnigeria.org

Ministry of Agriculture, Animal Industry and Fisheries [MAAIF]. (2011). Statistical Abstract 2011, Entebbe, Uganda.

Ministry of Agriculture, Animal Industry and Fisheries [MAAIF]. (2012). Uganda National Rice Development Strategy, 2008-2018. Kampala-Uganda.

Nakazi, F., \& Sserunkuuma, D. (2013). Factors Affecting the Decision and Extent of Ricemilling before Sale among Ugandan Farmers. Asian Journal of Agriculture and Rural Development, 3(8), 576-583.

Nijbroek, R. C., \& Andelman, S. J. (2016). Regional sustainability for agricultural intensification: a spatial analysis of the Southern Agricultural Growth Corridor of Tanzania. International Journal of Agricultural Sustainability,14(2), 231247.

Odogola, R. W. (2006). Japan International Cooperation Agency, (JICA) in collaboration with Sasakawa Africa Association Uganda. Final survey report on the status of rice production, processing and marketing in Uganda Submitted to the embassy of Japan in Uganda through JICA and Sasakawa Africa Association-Uganda, 31st March, 2006.

Rogers, E. M. (1995). Diffusion of innovations ( $4^{\text {th }}$ ed) New York. Journal of Agricultural Extension Education, 1(15),1-6.

Rugumamu, C. P. (2009). Assessment of post-harvest technologies and gender relations in maize loss reduction in Pangawe village eastern Tanzania. Tanzania Journal of Science, 35,1-76.

Seline, S. M., Delia, C., Oluyede, C. A., Gudeta, W. S., \& Maarten, N. (2015). The role of knowledge, attitudes and perceptions in the uptake of agricultural and agro forestry innovations among smallholder farmers in sub-Saharan Africa. International Journal of Agricultural Sustainability, 13(1), 40-54.

Tiamiyu, S. A., Akintola, J. O., \& Rahji, M. A. Y. (2009). Technology adoption and productivity difference among growers of New Rice for Africa in Savanna zone of Nigeria. 27(4), 193-197.

Tokida, K., Haneishi, Y., Tsuboi, T., Asea, G., \& Kikuchi, M. (2014). Evolution and prospects of the rice mill industry in Uganda. African Journal of Agricultural Research, 9(33), 2560-2573.

Uganda Bureau of Statistics [UBOS]. (2014). National Population and Housing Census 2014. Provisional Results. Revised Edition. November 2014, Kampala-Uganda.

World Bank. (2011). Missing food: The Case of Postharvest Grain Losses in Sub-Saharan Africa. Report No. 60371-AFR. April 2011, Washington D.C. 
Creative commons User License: CC BY-NC-ND

Abstracted by: EBSCOhost, Electronic Journals Service (EJS), Google Scholar, Directory of Open Access Journals (DOAJ), Journal Seek, Scientific Commons,

Food and Agricultural Organization (FAO), CABI and Scopus
Journal of Agricultural Extension

Vol. 21 (2) June, 2017

ISSN(e): 24086851; ISSN(Print); $1119944 X$

http://journal.aesonnigeria.org

http://www.ajol.info/index.php/iae

Email: editorinchief@aesonnigeria.org

Appendix 1: Determinants of factors with the perceived ability to reduce PHL in the Rice production chain

\begin{tabular}{|c|c|c|c|c|c|c|}
\hline \multirow{2}{*}{ Factor label and variables } & \multicolumn{6}{|c|}{ Component and factor loadings } \\
\hline & & 2 & 3 & 4 & 5 & 6 \\
\hline \multicolumn{7}{|l|}{$\begin{array}{l}\text { Contribution of the various modes of } \\
\text { Grain Quality Deterioration }\end{array}$} \\
\hline Rotting & 0.820 & 0.000 & 0.000 & 0.000 & 0.000 & 0.000 \\
\hline Molding & 0.810 & 0.000 & 0.000 & 0.000 & 0.000 & 0.000 \\
\hline Mixed varieties & 0.738 & 0.000 & 0.000 & 0.000 & 0.000 & 0.000 \\
\hline Delayed harvesting & 0.684 & 0.000 & 0.000 & 0.000 & 0.000 & 0.000 \\
\hline Grain discoloration (Yellowing) & 0.677 & 0.000 & 0.000 & 0.000 & 0.000 & 0.000 \\
\hline Pest damage & 0.568 & 0.000 & 0.000 & 0.000 & 0.000 & 0.000 \\
\hline Contamination with foreign matter & 0.502 & 0.000 & 0.000 & 0.000 & 0.000 & 0.000 \\
\hline \multicolumn{7}{|l|}{$\begin{array}{l}\text { Contribution of the various modes of } \\
\text { Physical Grain Loss }\end{array}$} \\
\hline Rodents and termites damage or losses & 0.000 & 0.762 & 0.000 & 0.000 & 0.000 & 0.000 \\
\hline Uncollected panicles & 0.000 & 0.643 & 0.000 & 0.000 & 0.000 & 0.000 \\
\hline Spillage losses & 0.000 & 0.642 & 0.000 & 0.000 & 0.000 & 0.000 \\
\hline Proportion of rice for sale & 0.000 & 0.000 & -0.960 & 0.000 & 0.000 & 0.000 \\
\hline Proportion of rice for home consumption & 0.000 & 0.000 & 0.832 & 0.000 & 0.000 & 0.000 \\
\hline $\begin{array}{l}\text { Proportion of rice for planting seeds } \\
\text { Labor availability on the farm }\end{array}$ & 0.000 & 0.000 & 0.628 & 0.000 & 0.000 & 0.000 \\
\hline Family labour & 0.000 & 0.000 & 0.000 & -0.869 & & 0.000 \\
\hline Hired labour & 0.000 & 0.000 & 0.000 & 0.869 & & 0.000 \\
\hline Number of years of rice farming & 0.000 & 0.000 & 0.000 & 0.000 & 0.801 & 0.000 \\
\hline Age of respondent in years & 0.000 & 0.000 & 0.000 & 0.000 & 0.798 & 0.000 \\
\hline Total household size & 0.000 & 0.000 & 0.000 & 0.000 & 0.536 & 0.000 \\
\hline \multicolumn{7}{|l|}{$\begin{array}{l}\text { Potential for expansion of area under } \\
\text { rice production }\end{array}$} \\
\hline $\begin{array}{l}\text { Amount of land allocated to rice } \\
\text { production }\end{array}$ & 0.000 & 0.000 & 0.000 & 0.000 & 0.000 & 0.821 \\
\hline Total land operated by the household & 0.000 & 0.000 & 0.000 & 0.000 & 0.000 & 0.758 \\
\hline Eigen value $\geq 1$ & 5.421 & 2.793 & 2.560 & 2.364 & 1.798 & 1.588 \\
\hline $\begin{array}{l}\text { Cumulative percent of variance explained } \\
(\%)\end{array}$ & 18.692 & 28.222 & 37.149 & 45.301 & 51.501 & 56.978 \\
\hline
\end{tabular}

